\title{
Epidemiologi ved korsryggsmerter
}

\author{
Dag Magnar Soldal \\ Revmatologisk avdeling, Sørlandet sykehus HF
}

\begin{abstract}
SAMMENDRAG
Artikkelen belyser lave korsryggsmerter med eller uten utstråling. Livstidsprevalensen for lave ryggsmerter er høy, sannsynligvis opp mot $80 \%$. På grunn av fravær fra arbeid, bruk av helsetjenester og produksjonstap fører rygglidelser til store kostnader for den enkelte og samfunnet. I 2004 var over 44000 personer uføretrygdet i Norge på grunn av rygglidelser, og rygglidelser er en av de viktigste enkeltårsaker til uføretrygd. Rygglidelser finnes $i$ alle aldersgrupper, og er like hyppig hos unge og eldre. Vi finner spesifikke årsaker til lave ryggsmerter i mindre enn $15 \%$ av tilfellene. Hos $1-5 \%$ finner en malign sykdom, betennelsesaktig revmatisk sykdom, frakturer eller skader. Hyppigste spesifikke årsak er skiveprolaps med nerverotsaffeksjon eller spinal stenose. Årsaken til uspesifikke rygglidelser mener vi i dag er multifaktorielle. Påvirkning av psykiske, sosiale og kulturelle faktorer kan føre til at tilstanden blir langvarig og tilbakevendende selv om mulige primære biologiske årsaker etter hvert har mindre betydning. En del faktorer som røyking, betydelig overvekt, mye løfting, vridning, ensformig arbeid, helkroppsvibrasjon, samt mistrivsel i jobbsituasjonen er vist å henge sammen med økt rapportering av symptomer. For samtlige av disse faktorene er assosiasjonene varierende og ikke sterke. Prognosen ved akutte ryggsmerter er vanligvis god. Studier viser at etter en måned var reduksjon i smerte og arbeidsuførhet på $58 \%$, og at hele $82 \%$ var kommet tilbake i jobb. Etter ett år er mindre enn 5\% sykmeldte. Likevel opplever opptil $20 \%$ betydelig funksjonsbegrensning pga. ryggsmerter etter ett år. Prognosen er noe dårligere hos pasienter med utstråling av smerter til beina. En rekke andre og ikke-ryggrelaterte faktorer som lav utdanning og lav sosioøkonomisk status karakteriserer personer med rygglidelser som faller ut av arbeidslivet.
\end{abstract}

Soldal DM. The epidemiology of low back pain. Nor J Epidemiol 2008; 18 (1): 107-110.

\section{ENGLISH SUMMARY}

Low back pain (LBP) is a major reason for disability in Norway, and LBP therefore has great impact on both the individual person suffering from LBP and for the society. The lifetime prevalence for LBP is high, about $80 \%$, but the prognosis is good for individual episodes. After the first attack $50 \%$ is well in one week and $90 \%$ in 8 weeks. Only in about $15 \%$ we know the reason for LBP, with radicular pain from spinal disc herniation as the major cause. Unspecific LBP has multiple risk factors for disability such as psychological factors, low education and lifestyle factors.

I denne artikkelen vil vi belyse epidemiologiske forhold ved smerter knyttet til korsrygg med eller uten utstrålende smerter. Vi vil ikke ta for oss nakkelidelser eller torakale ryggsmerter, som til sammen rammer betydelig færre enn de personer som har smerter som utgår fra korsryggen. Korsryggsmerter er definert som smerter mellom 12. ribbein og glutealfoldene. I tillegg kan pasienten oppleve smerter som stråler ut i underekstremitetene (1).

Fra 70-tallet til ca. 1995 søkte personer i økende grad helsevesenet for å få behandling for korsrygglidelser. Siden det ikke er holdepunkter for økende grad av rygglidelser i befolkningen, mener man at den økte søkning til behandling skyldes et komplekst samspill mellom nedsatt aksept for det å ha smerter og økende mulighet for utredning, som for eksempel flere røntgen- og MR-undersøkelser, flere behandlingstilbud av varierende nytte og lettere tilgang på trygdestønader. Denne utviklingen har stagnert de siste ti år, uten at vi vet årsaken til det. Kanskje har det sammenheng med et bedre samspill mellom de nevnte faktorene (2).
Det er vanlig å skille mellom akutte ryggsmerter som varer mindre enn tre måneder og langvarige (kroniske) som varer mer en tre måneder. En undergruppe av de akutte er subakutte ryggsmerter som en betegnelse på smerter som varer mer enn 6 uker, men mindre enn tre måneder $(3,4)$. Denne inndelingen $\mathrm{i}$ akutt og langvarig ryggsmerte er tilfeldig satt, og det finnes ikke noe vitenskaplig grunnlag for dette. Det er mulig at man epidemiologisk ville ha bedre nytte av å telle smertedager i løpet av ett år (5). Pasienter med mindre enn 30 smertedager i løpet av ett år skiller seg fra gruppen med flere smertedager når det gjelder alder, kjønn, røykevaner, arbeidsbelastning og tro på egen mestring ("health locus of control") $(6,7)$.

\section{Prevalens Og INSIDENS}

Korsryggrelaterte plager rammer svært mange av oss $\mathrm{i}$ løpet av livet. Både i norske og internasjonale undersøkelser er det vist at livstidsprevalensen for korsryggsmerter med eller uten radikulære smerter til beina er 
høy, og varierer i de ulike studier mellom 49 og $84 \%$ (8). Siden ryggplager ofte fører til fravær fra arbeid, er konsekvensene for den enkelt og for samfunnet store, og selv om rygglidelser svært sjelden er dødelige, koster de samfunnet og den enkelte som rammes betydelig i form av bruk av helsetjenester, sykefravær og produksjonstap. I et norsk materiale utgjorde ryggpasienter $82 \%$ av kiropraktorenes pasientkontakter, 27\% av fysioterapeuter/manuellterapeuters og $10 \%$ av fastlegenes konsultasjoner (9). Fra fastlegene blir 10\% henvist til spesialisthelsetjenesten, og de fleste større sykehus mottar i dag ryggpasienter i ryggpoliklinikker som er tverrfaglige og med samarbeid på tvers av spesialitetene.

Ryggsmerter residiverer ofte, og for en ryggpasient kan det være gradvise overganger mellom gode perioder og tilbakefall med varierende smerteintensitet og varighet. I en engelsk studie fra allmennpraksis fant man at hele $7 \%$ av befolkningen søkte lege for nyoppståtte ryggsmerter i løpet av ett år (10). 3/4 av disse pasientene hadde ryggplager ett år etter første konsultasjon. Prognosen ved enkeltepisoder med uspesifikke ryggsmerter er likevel regnet for å være god. De fleste ryggepisoder går over, slik at $50 \%$ er bra etter en uke og 90\% etter 8 uker. Risikoen for tilbakefall er likevel relativt stor.

Ryggplager gir hyppigst arbeidsmessige begrensninger hos personer mellom 30 og 50 år, men plagene er til stede på ulike tider i livet hos den enkelte som rammes, og har da ofte betydning i form av redusert funksjon i en periode på 5-15 år. Hos unge ser det ut til at forekomst av ryggsmerter øker gradvis med alderen og når nivået til voksen befolkning ved 18-årsalderen, selv om smertelokalisasjon og beskrivelse av ryggplager for øvrig spriker mye i ulike studier av ryggsmerter hos barn og unge (11). Brage og Lærum viste i en norsk studie at av den voksne befolkningen hadde vel $50 \%$ hatt korsryggrelaterte plager det siste året. Dagsprevalensen var i dette studiet på $15 \%$ (12). Hos personer over 65 år vet vi mindre om forekomsten fordi det er så stor spredning $\mathrm{i}$ de studier som foreligger, men sannsynligvis er det like hyppig med korsryggrelaterte plager $\mathrm{i}$ den eldre som $\mathrm{i}$ den yngre befolkningen $(13,14)$.

\section{ÅRSAKER OG RISIKOFAKTORER}

Ved korsryggrelaterte lidelser er det gjort et skille mellom spesifikke og uspesifikke rygglidelser (8). Mindre enn $15 \%$ av de korsryggrelaterte smertene har spesifikke årsaker. Da dreier det seg om betennelseaktige revmatiske rygglidelser, smerte forårsaket av malign sykdom og frakturer eller skader hos 1-5\% av pasientene. Hyppigste årsak (hos 5-10\%) er forandringer som gir nerverotsaffeksjoner, som mellomvirvelskiveprolapser eller tranghet (stenose) i spinalkanalen eller rotkanaler som gir radikulære smerter. Refererte smerter fra andre organer er også årsak til ryggsmerter, og slike årsaker må være med i vurderingen og utredningen av ryggsmerter. Studier i primærhelsetjenesten tyder på at $4 \%$ av pasienter som behandles for ryggsmerter har en kompresjonsfraktur og mindre enn $1 \%$ malign sykdom (15). Dersom vi definerer isjias som nerverotssmerte, er prevalensen 3-5\% hos menn og 1$4 \%$ hos kvinner. Selv ved nerverotssmerte blir færre enn $5 \%$ av pasienter med prolaps operert (16). Noe flere menn enn kvinner blir operativt behandlet.

Årsakene til uspesifikke rygglidelser mener vi i dag er multifaktorielle. Ulike studier har pekt på genetiske (17-20), vaskulære $(13,21)$ og livsstilsrelaterte $(5,6,22$, 23) årsaker til ryggplager. Smertene kan primært være nociceptive perifere smerter og utgår da fra strukturer $i$ ryggen. Etter en tid kan smertene bli sentraliserte og komplekse med påvirkning av psykiske, sosiale og kulturelle faktorer. Disse faktorene kan medvirke til at tilstanden blir langvarig og tilbakevendende selv om de primære biologiske årsaker etter hvert har mindre betydning.

Ulike strukturer i ryggsøylen gir sannsynligvis så like smerteopplevelser at vi ikke kan skille den ene strukturen fra den andre. Det mangler også spesifikke undersøkelser som med sikkerhet kan skille strukturene fra hverandre. Likevel er det sannsynlig at mellomvirvelskivedegenerasjon og følge av slike forandringer kan forklare en del av de uspesifikke korsryggsmertene. Ved MR-undersøkelser kan vi se såkalte Modic-forandringer som en mener er følge av at det siver ut nukleusvev fra skiven gjennom dekkplatene og ut i de tilstøtende vertebra (25). Dette gir en inflammasjon og senere fettdegenerasjon i knokkelen. Sammenhengen mellom funn av degenerative forandringer ved vanlig skjelettundersøkelser og ryggsmerter er liten (26). Faktorer som røyking, betydelig overvekt og lite mosjon er belyst i flere studier og forklarer en liten del av variasjonen i ryggplager. Mye løfting, vridning, ensformig arbeid, helkroppsvibrasjon, samt mistrivsel i jobbsituasjonen er vist å henge sammen med økt rapportering av symptomer $(23,24)$. For samtlige av disse faktorene er assosiasjonene varierende og ikke sterke. I en norsk studie av pasienter sykmeldte for korsryggsmerter hadde pasientene økt risiko for å rapportere smerte i armer, skuldre, nakke og føttene, hodepine, migrene, søvnproblemer, hetetokter, angst og depresjon (27).

\section{PrognOSE OG FORLØP}

I en systematisk oversikt fant man ved akutte ryggsmerter at det i løpet av en måned var reduksjon $\mathrm{i}$ smerte og arbeidsuførhet på 58\%, og at hele $82 \%$ var kommet tilbake i jobb (28). Imidlertid hadde $73 \%$ fått ett eller flere tilbakefall i løpet av det kommende året. Etter ett år hadde 33\% vekslende eller vedvarende ryggsmerter i moderat grad og $20 \%$ var så plaget at de opplever betydelig funksjonsbegrensning (29). Tallene er forskjellige i ulike studier fordi man ofte ikke skiller mellom personer med residiverende ryggplager avløst av gode perioder, og personer som hadde fått sin første ryggepisode. De som har hatt en ryggepisode, har bedre prognose med halvparten så hyppige tilbakefall 
som personer som har hatt en eller flere ryggepisoder tidligere.

Pasienter med isjias, og da særlig hvis det påvises mellomvirvelskiveprolaps, har lengre sykefravær enn pasienter med korsryggsmerter uten utstråling. En norsk studie har vist at syv uker ut i sykdomsforløpet er $35 \%$ av pasienter med radikulære smerter fremdeles sykmeldt, mens tallet er $16 \%$ for gruppen uten utstråling (12). Etter ett år er $6 \%$ av ryggpasienter med utstrålende smerter fortsatt sykmeldt, mens 2,5\% av pasienter uten utstråling har sykmelding. De fleste får imidlertid en rask bedring, slik at selv pasienter som behandles uten operasjon opplever markert reduserte smerter etter 4 uker og hele $80 \%$ blir bra i løpet av 3 måneder (30). Operasjon er vanligvis ikke nødvendig bortsett fra hos de pasientene som får et cauda equinasyndrom eller progredierende pareser ved store prolaps. Ved intraktable isjias-smerter kan også operasjon være nødvendig.

\section{KONSEKVENSER}

De direkte og indirekte kostnader knyttet til korsrygglidelser er her i landet på mellom 13 og 15 milliarder årlig. Korsrygglidelser er en av de viktigste enkeltårsaker til uføretrygd i Norge, og hvert år blir 3000-4000 uføretrygdet på grunn av rygglidelser. I 2004 var over
44000 personer uføretrygdet på grunn av rygglidelser (31). Det ser ut til at pasienter med sammensatte smerter i muskel- skjelettsystemet har dårligere arbeidevne enn pasienter som bare rapporterer korsryggsmerter (32).

Det er dokumentert at psykososiale faktorer er generelt viktigere for prognosen i forhold til å komme tilbake på jobb enn biomedisinske faktorer (som for eksempel vekt, muskelstyrke, bevegelighet) (33-38). Slike psykososiale faktorer er pessimistisk smerteadferd, der pasienten opplever at smerten varsler noe farlig, videre er arbeidsrelaterte problemer som mistrivsel og lav autonomi viktig, samt emosjonelle problemer som depresjon, angst og stress (39). Forventninger til forsikrings- og trygdeytelser kan også virke negativt inn på prognosen $(39,40)$.

Sjansen for å bli friskmeldt etter sykmelding for korsrygglidelser synes å være påvirket av andre faktorer enn bare ryggsmerter. Lav fysisk aktivitet, mangel på energi, fysisk ryggbelastende tungt arbeid, og lav forventning om å komme tilbake $\mathrm{i}$ jobb er prediktorer for å ikke komme tilbake i jobb etter ett år $(41,42)$. Andre risikofaktorer for å falle ut av arbeidslivet er lite utdanning og lav sosioøkonomisk status. Dårlig sosial støtte ser også ut til å ha betydning. Når flere av disse faktorene karakteriserer en person blir prognosen med hensyn på komme tilbake på jobb enda dårligere (32, 41,43,44).

\section{REFERANSER}

1. Nasjonalt ryggnettverk 2001.

2. Bendix T, Manniche C. Rygsmerter. Ugeskr Lager 2006; 168 (20): 1954-7.

3. Natvig B, Picavet HS. The epidemiology of soft tissue rheumatism. Best Pract Res Clin Rheumatol 2002; 16 (5): 777-93.

4. Croft P, Papageorgiou A, McNally R. Low back pain. Health care needs assessment. Second Series. Oxford Radcliffe Medical Press, 1997: 129-82.

5. Leboeuf-Yde C, Kyvik K, Bruun N. Low back pain and lifestyle. Part II: Obesity. Information from a population-based sample of 29,424 twin subjects. Spine 1999; 24 (8): 783-4.

6. Leboeuf-Yde C, Kyvik K, Bruun N. Low back pain and lifestyle. Part I: Smoking. Information from a population-based sample of 29,424 twins. Spine 1998; 23 (20): 2207-13.

7. Leboeuf-Yde C, Lauritsen J, Lauritzen T. Why has the search for causes of low back pain largely been nonconclusive? Spine 1997; 15 (22): 877-81.

8. van Tulder M, Becker A, Bekkering T, Breen A, del Real MT, Hutchinson A et al. Chapter 3. European guidelines for the management of acute nonspecific back pain in primary care. Eur Spine $J$ 2006; 15 (Suppl 2): S169-9

9. Werner E, Indahl A. Kunnskap praksis og holdninger til rygglidelser hos leger, fysioterapeuter og kiropraktorer. Tidsskr Nor Lageforen 2005; 125 (13): 1794-7.

10. Croft PR, Macfarlane GJ, Papageorgiou AC Thomas E, Silman AJ. Outcome of low back pain in general practice: a prospective study. $B M J 1998 ; 316$ (7141): 1356-9.

11. Jeffries LJ, Milanese SF, Grimmer-Somers KA. Epidemiology of adolescent spinal pain: a systematic overview of the research literature. Spine 2007; 32 (23): 2630-7.

12. Brage S, Lærum E. Rygglidelser i Norge - en epidemiologisk beskrivelse. Tidsskr Nor Laegeforen 1999; 119: $1619-23$.

13. Bressler H, Keyes W, Rochon P, Badley E. The prevalence of low back pain in the elderly. A systematic review. Spine 1999; 24 (17): 1813-9.

14. Hartvigsen J, Christensen K, Frederiksen H. Back pain remains a common symptom in old age. A populationbased study of 4486 Danish twins aged 70-102. Eur Spine J 2003; 12: 528-34. 
15. Svensson H-O, Vedin A, Wilhelmsson C, Andersson G. Low-back pain in relation to other diseases and cardiovascular risk factors. Spine 1983; 8: 277-85.

16. Lærum E, Dullerud R, Grundnes O, Haagensen $\varnothing$, Indahl A, Ljunggren A. Lumbalt skiveprolaps med rotaffeksjon. Oslo: Senter for medisinsk metodevurdering, 2001. Report No. 1/2001.

17. Bozzao A, Gallucci M, Masciocchi C, Aprile I, Barile A, Passariello R. Lumbar disk herniation: MR imaging assessment of natural history in patients treated without surgery. Radiology 1992; 185 (1): 135-4.

18. Matsui H, Kanamori M, Ishihara H, Yudoh K, Naruse Y, Tsuji H. Familial predisposition for lumbar degenerative disc disease. A case-control study. Spine 1998; 23 (9): 1029-3.

19. Richardson J, Chung T, Schultz J, Hurvitz E. A familial predisposition towards lumbar disc injury. Spine 1997; 22 (13): 1487-92.

20. Videman T, Leppavuori J, Kaprio J, Battie M, Gibbons L, Peltonen L et al. Intragenic polymorphism of the vitamin D receptor gene associated with intervertebral disc degeneration. Spine 1998; 23 (23): 2477-85.

21. Kauppila L, Tallroth K. Postmortem angiographic findings for arteries supplying the lumbar spine: their relationship to low-back symptoms. J Spinal Disord 1993; 6 (2): 124-9.

22. Hagen K, Tambs K, Bjerkedal T. A prospective cohort study of risk factors for disability retirement because of back pain in the general working population. Spine 2002; 27 (16): 1790-6.

23. Burton A, Tillotson K, Symonds T, Burke C, Mathewson T. Occupational risk factors for for the first-onset and subsequent course of low back trouble: A study of serving police officers. Spine 1996; 21 (22): 2612-20.

24. Lings S, Leboeuf-Yde C. Whole-body vibration and low back pain: A systematic, critical review of the epidemiological literature 1992-1999. Int Arch Occup Environ Health 2000; 73 (5): 290-7.

25. Kjaer P, Leboeuf-Yde C, Korsholm L, Sorensen JS, Bendix T. Magnetic resonance imaging and low back pain in adults: a diagnostic imaging study of 40-year-old men and women. Spine 2005; 30: 1173-80.

26. Kendrick D, Fielding K, Bentley E, Miller P, Kerslake R, Pringle M. The role of radiography in primary care patients with low back pain of at least 6 weeks duration: a randomised (unblinded) controlled trial. Health Technol Assess 2001; 5 (30): 1-69.

27. Hagen EM, Svensen E, Eriksen HR, Ihlebaek CM, Ursin H. Comorbid subjective health complaints in low back pain. Spine 2006; 31 (13): 1491-5.

28. Pengel L, Herbert R, Maher C, Refshauge K. Acute low back pain: systematic review of its prognosis. $B M J$ 2003; 327 (7410): 323.

29. Hestbæk L, Leboeuf-Yde C, Manniche C. Low back pain: what is the long-term course? A review of studies of general patient populations. Eur Spine J 2003; 12 (2): 149-65.

30. Weber H. Lumbar disc herniation. A controlled, prospective study with ten years of observation. Spine 1983; $8(2): 131-40$

31. Trygdestatisk årbok 2005.

32. Hoddevik GH, Selmer R. [Chronic low back pain in 40-year olds in 12 Norwegian counties] Tidsskr Nor Loegeforen 1999; 119: 2224-8.

33. Cedraschi C, Allaz A. How to identify patients with a poor prognosis in daily clinical practice. Best Pract Res Clin Rheumatol 2005; 19 (4): 577-91.

34. Grotle M, Brox J, Veierod M, Glomsrod B, Lonn J, Vollestad N. Clinical course and prognostic factors in acute low back pain: patients consulting primary care for the first time. Spine 2005; 30 (8): 976-82.

35. Grotle M, Vollestad N, Veierod M, Brox J. Fear-avoidance beliefs and distress in relation to disability in acute and chronic low back pain. Pain 2004; 112 (3): 343-52.

36. Haldorsen E, Kronholm K, Skouen J, Ursin H. Multimodal cognitive behavioral treatment of patients sicklisted for musculoskeletal pain: a randomized controlled study. Scand J Rheumatol 1998; 27 (1): 16-25.

37. Hunt D, Zuberbier O, Kozlowski A, Berkowitz J, Schultz I, Milner R et al. Are components of a comprehensive medical assessment predictive of work disability after an episode of occupational low back trouble? Spine 2002; 27 (23): 2715-9.

38. Ursin H. Prognose ved rygglidelser. Tidsskr Nor Lageforen 1999; 119: 1909-12.

39. Schultz I, Crook J, Meloche G, Berkowitz J, Milner R, Zuberbier O et al. Psychosocial factors predictive of occupational low back disability: towards development of a return-to-work model. Pain 2004; 107 (1-2): 77-85.

40. Waddell G. The back pain revolution. Edinburgh: Churchill Livingstone, 1998.

41. Haldorsen EM, Indahl A, Ursin H. Patients with low back pain not returning to work. A 12-month follow-up study. Spine 1998; 23 (11): 1202-7.

42. Hagen EM, Eriksen HR, Ursin H. Does early intervention with a light mobilization program reduce long-term sick leave for low back pain? Spine 2000; 25 (15): 1973-6.

43. Hoeijenbos M, Bekkering T, Lamers L, Hendriks E, van Tulder M, Koopmanschap M Cost-effectiveness of an active implementation strategy for the Dutch physiotherapy guideline for low back pain. Health Policy 2005; 75 (1): 85-98.

44. SBU. Ont i ryggen, ont i nacken. En evidensbaserad kunskapssammanställning. Stockholm: SBU (Statens beredning för medicinsk utvärdering), 2000. Report No. 145. 